\title{
Organic biomarkers in deep-sea regions affected by bottom trawling: pigments, fatty acids, amino acids and carbohydrates in surface sediments from the La Fonera (Palamós) Canyon, NW Mediterranean Sea
}

\author{
E. Sañé, J. Martín, P. Puig, and A. Palanques \\ Institut de Ciències del Mar, CSIC. Passeig Marítim de la Barceloneta, 37-49, 08003 Barcelona, Spain \\ Correspondence to: E. Sañé (sane@icm.csic.es)
}

Received: 26 November 2012 - Published in Biogeosciences Discuss.: 18 December 2012

Revised: 26 October 2013 - Accepted: 30 October 2013 - Published: 11 December 2013

\begin{abstract}
Deep-sea ecosystems are in general adapted to a limited variability of physical conditions, resulting in high vulnerability and slow recovery rates from anthropogenic perturbations such as bottom trawling. Commercial trawling is the most recurrent and pervasive of human impacts on the deep-sea floor, but studies on its consequences on the biogeochemistry of deep-sea sediments are still scarce. Pigments, fatty acids, amino acids and carbohydrates were analysed in sediments from the flanks of the La Fonera (Palamós) submarine canyon (NW Mediterranean Sea), where a commercial bottom trawling fishery has been active for more than $70 \mathrm{yr}$. More specifically, we investigated how trawlinginduced sediment reworking affects the quality of sedimentary organic matter which reaches the seafloor and accumulates in the sediment column, which is fundamental for the development of benthic communities. Sediment samples were collected during two oceanographic cruises in spring and autumn 2011. The sampled sites included trawl fishing grounds as well as pristine (control) areas. We report that bottom trawling in the flanks of the La Fonera Canyon has caused an alteration of the quality of the organic matter accumulated in the upper $5 \mathrm{~cm}$ of the seafloor. The use of a wide pool of biochemical tracers characterized by different reactivity to degradation allowed for us to discriminate the long-term effects of trawl-induced sediment reworking from the natural variability caused by the seasonal cycle of production and sinking of biogenic particles. Differences between untrawled and trawled areas were evidenced by labile amino acids, while differences between spring and autumn samples were detected only by the more labile indicators
\end{abstract}

chlorophyll $a$ and monounsaturated fatty acids. These results suggest that changes in the biochemical composition of the sedimentary organic matter caused by bottom trawling can be more relevant than those associated with natural seasonality and pose serious concerns about the ecological sustainability of deep-sea trawling activities.

\section{Introduction}

Commercial bottom trawling is a fishing activity that consists in pulling heavy fishing gear over the seafloor, with negative effects on the sedentary macrofauna and on fish stocks (Jones, 1992; McConnaughey et al., 2000; Thrush and Dayton, 2002; Morato et al., 2006; Thrush and Dayton, 2010). Over the last decades, commercial fishing has been extending its operations over larger and deeper areas of the world's oceans (Bensch et al., 2009). It has been recently estimated that the overall oceans' area (including continental shelf regions and seamounts) used as trawling grounds accounts for 20 million $\mathrm{km}^{2}$ (World Resources Institute, 2000), of which about one-fourth is located on the continental slope regions (Puig et al., 2012). Due to their low resilience, deepwater areas $(>200 \mathrm{~m})$ are more vulnerable to anthropogenic disturbance than shallow, high-energy environments (McConnaughey et al., 2000), and for this reason, the effects of bottom trawling on the deep benthic communities and their habitats need to be studied carefully. 
Submarine canyons are morphological incisions traversing continental margins that have the capacity to facilitate the transport of dissolved and particulate matter from continental shelves to deeper waters (Granata et al., 1999; Allen and Durrieu de Madron, 2009; Palanques et al., 2011), and therefore are sites of high productivity and organic matter enrichment (Vetter and Dayton, 1999; García and Thomsen, 2008; De Leo et al., 2010; Vetter et al., 2010) where benthic communities are favoured by food availability. Not surprisingly, submarine canyons harbour valuable stocks of living resources and their surroundings are often targeted by commercial fisheries for purposes such as bottom trawling (Company et al., 2012).

This study focuses on the flanks of the La Fonera Canyon (also known as Palamós Canyon), where a monospecific otter trawl fishery targeting the deep-water shrimp Aristeus antennatus has been active for more than 70 years to depths of up to $800 \mathrm{~m}$ (Tobar and Sardà, 1987). Previous studies have shown that bottom trawling along the flanks of the La Fonera Canyon can trigger sediment gravity flows (Palanques et al., 2006), which transport sediments downslope from the fishing grounds into the canyon axis (Martín et al., 2006, 2007), affecting sediment accumulation rates in the lower canyon (Martín et al., 2008) and ultimately altering the morphology of the canyon flanks as a result of chronic reworking and removal of sediments (Puig et al., 2012).

This work aims to assess the effects of bottom trawling on the quality of the organic matter in surface sediments by comparing regions affected and unaffected by this fishing technique. The quantity and the quality of the organic matter settling on the seabed represent important factors regulating benthic biomass (Grebmeier et al., 1988) and are important for the development of benthic communities (Thompson and Nichols, 1988; Graf, 1989). Organic matter indicators have been already used to address the biochemical composition of sediments in submarine canyons (García and Thomsen, 2008; Pusceddu et al., 2010; Pasqual et al., 2011). Here, we utilized biomarkers characterized by different susceptibilities to environmental conditions. Pigments and unsaturated fatty acids, the most labile compounds (Haddad et al., 1992; Wakeham et al., 1997), are good indicators of fresh organic matter, whereas carbohydrates are considered the most refractory macromolecules (Wakeham et al., 1997). Protein and neutral amino acids are less labile than pigments and unsaturated fatty acids, but like them, they are utilized as indicators of labile material (Mayer et al., 1995; Lee et al., 2004). The use of this combination of biomarkers will allow for us to study the effects of sediment reworking by trawling on the quality of the organic matter as well as compare them with those related to seasonal variability, being that sediment samples were collected both in spring and in autumn.

\section{Materials and methods}

\subsection{Sampling}

Coring stations were chosen based on the distribution of fishing grounds in the La Fonera Canyon, which is well known thanks to the satellite-based navigation tracks of bottom trawlers (i.e. vessel monitoring system (VMS) data) (Fig. 1). Trawling activities are conducted on the flanks of the canyon between 350 and $800 \mathrm{~m}$ depth along two main fishing grounds: Sant Sebastià on the northern flank and Rostoll on the southern flank (Fig. 1). The offshore sector of the southern flank remains unexploited by the trawling fleet and therefore will be used as a control site.

Samples were taken on board RV García del Cid during two oceanographic cruises: HERMIONE I in spring 2011 (SPR), and HERMIONE II in autumn 2011 (AUTM). Station names, depths, coordinates and sampling dates are listed in Table 1 (see also Fig. 1). Two regions were targeted in the study area: an untrawled region in the offshore southern canyon flank (UTR: stations SF-3, SF-4, SF-5 and SF-6) and a trawled region comprising both the northern canyon flank and the inshore southern flank (TR: stations NF-1, NF2, NF-3, NF-4, NF-5, NF-6, SF-1 and SF-2). All sampling stations were located within a water depth range of approximately $450-600 \mathrm{~m}$. Sediment samples were taken using a KC multi-corer equipped with six polycarbonate tubes with an inner diameter (i.d.) of $9.4 \mathrm{~cm}$. From each station, a tube with an undisturbed sediment-water interface was selected for analysis. During the SPR cruise, the multi-corer tubes were sub-sampled down to $5 \mathrm{~cm}$ with smaller tubes (i.d. $3.5 \mathrm{~cm}$ ) that were immediately frozen at $-20^{\circ} \mathrm{C}$. During the AUTM cruise, the multi-corer tubes were directly sub-sampled on board in $1 \mathrm{~cm}$ slices from the top to $5 \mathrm{~cm}$ depth and subsamples were stored in plastic bags at $-20^{\circ} \mathrm{C}$.

Except for the offshore part of the northern canyon flank (NF-5 and NF-6), the top $5 \mathrm{~cm}$ of the sediment column at sampled sites was basically composed of silty mud with variable amounts of sand (1-14\%). We noticed that along the northern canyon flank the coarseness of the topmost sediments increased seawards. Given the wide differences in the textural properties compared with all the other stations, the station NF-5 was thereafter discarded for statistical analysis. Regarding NF-6, it could not be sampled due to the stiffness of bottom sediments at that station. In previous works, no substantial differences between the northern and southern canyon flanks were observed in terms of the composition of downward particulate matter fluxes collected by sediment traps (Martín et al., 2006); hence, for the purpose of this study, we assume that there are no major natural compositional differences between the trawled and untrawled pool of samples. 
Table 1. Names, depths, coordinates and sampling dates of the coring stations. Trawled (TR) and untrawled (UTR) regions as well as spring (SPR) and autumn (AUTM) sampling seasons corresponding to each station are also indicated.

\begin{tabular}{lccclll}
\hline Station & $\begin{array}{c}\text { Depth } \\
(\mathrm{m})\end{array}$ & $\begin{array}{c}\text { Latitude }^{\circ} \mathrm{N} \\
(\text { decimal })\end{array}$ & $\begin{array}{c}\text { Longitude }^{\circ} \mathrm{E} \\
(\text { decimal })\end{array}$ & $\begin{array}{l}\text { Sampling } \\
\text { date }\end{array}$ & $\begin{array}{l}\text { Trawling } \\
\text { region }\end{array}$ & $\begin{array}{l}\text { Sampling } \\
\text { season }\end{array}$ \\
\hline NF-1 & 475 & 41.8853 & 3.3070 & 12 October 2011 & TR & AUTM \\
NF-2 & 500 & 41.8860 & 3.3321 & 13 May 2011 & TR & SPR \\
NF-3 & 591 & 41.8903 & 3.3495 & 12 October 2011 & TR & AUTM \\
NF-4 & 486 & 41.8892 & 3.3785 & 12 October 2011 & TR & AUTM \\
NF-5 & 556 & 41.8890 & 3.4093 & 12 May 2011 & TR & SPR \\
NF-6 & 470 & 41.8978 & 3.4257 & 12 October 2011 & TR & AUTM \\
SF-1 & 463 & 41.8512 & 3.2912 & 12 October 2011 & TR & AUTM \\
SF-2 & 503 & 41.8340 & 3.3178 & 13 May 2011 & TR & SPR \\
SF-3 & 457 & 41.8150 & 3.3433 & 12 October 2011 & UTR & AUTM \\
SF-4 & 453 & 41.8102 & 3.3652 & 11 October 2011 & UTR & AUTM \\
SF-5 & 472 & 41.8075 & 3.3872 & 13 May 2011 & UTR & SPR \\
SF-6 & 498 & 41.7942 & 3.4075 & 11 October 2011 & UTR & AUTM \\
\hline
\end{tabular}

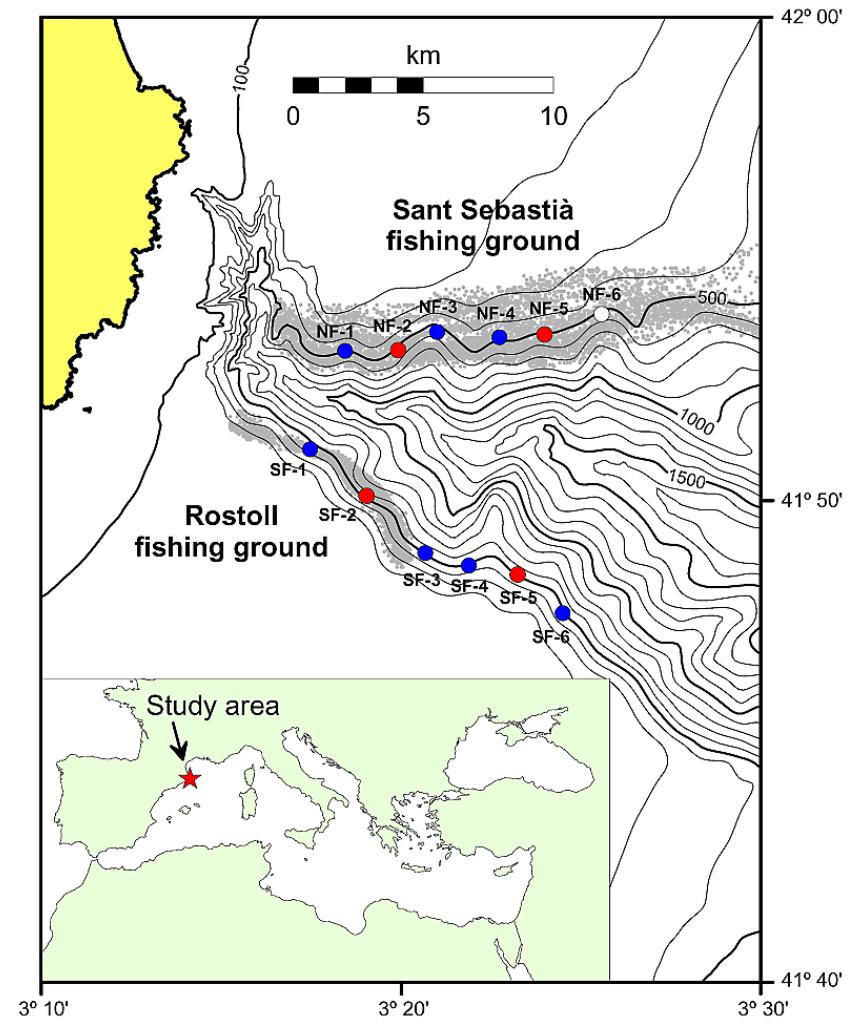

Fig. 1. Bathymetric chart of the La Fonera (Palamós) Canyon showing the locations of sediment sampling stations. The main fishing grounds active on the canyon flanks are defined by the clouds of grey points corresponding to vessel monitoring system (VMS) positions from Palamós harbour trawlers (see Puig et al., 2012 for details). Red dots correspond to coring stations visited in spring 2011 and blue dots to stations visited in autumn 2011. No sediment samples could be retrieved from station NF-6 (white dot) due to the extreme stiffness of bottom sediments at that site (see the text for details).

\subsection{Laboratory analysis}

Frozen sediment samples were freeze-dried $(P=0.1 \mathrm{mbar}$ and $T=-80^{\circ} \mathrm{C}$ ) for $24 \mathrm{~h}$ and prepared for analysis by highperformance liquid chromatography (HPLC) (pigments, amino acids and carbohydrates) or gas chromatography (GC) (fatty acids). The SPR surface sediment samples kept in the small tubes were subsampled at $1 \mathrm{~cm}$ intervals down to $5 \mathrm{~cm}$ to have the same vertical resolution as the AUTM sediment samples. Laboratory analyses were carried out on all single samples from 0 to $5 \mathrm{~cm}$ depth, although for some analyses there was not enough material left from specific centimetres (see Supplement A, B, C and D).

The percentage of total organic carbon in dried and ground samples was obtained by means of a LECO CN-2000 autoanalyser after treatment with $\mathrm{HCl}$ to remove inorganic carbon. Blanks and standards (analytical grade EDTA, Sigma) were intercalated within sets of samples to calibrate the measurements.

\subsubsection{Pigments}

Pigments were extracted from sediments using the methodology described by Sun et al. (1991) and analysed by HPLC following the protocol detailed by Wright et al. (1991). For each sample, pigments were extracted from sediments by adding $3 \mathrm{~mL}$ of pure acetone to approximately $2 \mathrm{~g}$ of freezedried sediment. After vortex mixing, samples were placed in an ultrasonic bath for $10 \mathrm{~min}$ and then centrifuged at $3000 \mathrm{rpm}$ for $10 \mathrm{~min}$. After recovering $1.5 \mathrm{~mL}$ of the supernatant, the entire procedure was repeated a second time in order to obtain for each sample approximately $3 \mathrm{~mL}$ of extract. Finally, the pigment extracts were evaporated with nitrogen, re-diluted with $200 \mu \mathrm{L}$ of pure acetone, filtered with syringe nylon filters (pore diameter $0.45 \mu \mathrm{m}$ ) and transferred to HPLC vials for their later analysis. 
Pigments were analysed with a W-600 controller coupled with a W717 autosampler using the technique HPLC-FPdiode array detector (DAD) (Gradient). The column was a $C_{18}$ Prontosil-AA-FMOC $5 \mu \mathrm{m}(250 \mathrm{~mm} \times 4 \mathrm{~mm})$. A Waters DAD 2996 (436 nm) and a Jasco FP-1520 (Ex. $440 \mathrm{~nm}$, Em. $660 \mathrm{~nm}$ ) were used as detectors. The mobile phase consisted of three solutions, A (methanol and ammonium acetate $0.5 \mathrm{M}, 4: 1 v / v$ ), B (acetonitrile and Milli-Q water, $9: 1$ $v / v$ ) and $\mathrm{C}$ (ethyl acetate, HPLC grade). The velocity of the flux was $0.9 \mathrm{~mL} \mathrm{~min}^{-1}$ and the pressure $2500 \mathrm{psi}$. The volume of injection was $100 \mu \mathrm{L}$ and the run time 34 minutes. The gradient is described in Wright et al. (1991). A mixed pigments standard (DHI) was also analysed. Pigment peaks were identified in the chromatogram using the Empower software, which is specifically for the treatment of chromatographic data. Pigments were identified by knowing their retention times in the column and the wavelength of maximum absorbance characteristic for each pigment.

Among pigments, chlorophyll $a(\mathrm{Chl} a)$ was used as an indicator of labile organic matter, whereas carotenoids (peridin, fucoxanthin, diatoxanthin, lutein, zeaxanthin and canthaxanthin) were used as refractory organic matter indicators. The Chl $a$-to-pheophytin $a$ (Pheo $a$ ) ratio and the sum of the Chl $a$ degradation products (pheophytin $a$, pheophorbide $a$ and pyropheophorbide $a$ ) were used as degradation indexes.

Pigment relative abundances are expressed as percentages.

\subsubsection{Fatty acids}

Fatty acids (FA) were extracted through a one-step transesterification process (Lewis et al., 2000; Christie, 2003; Indarti et al., 2005) modified to be applied on marine matrixes (algae and sediments) (Nahon et al., 2010; Bourgeois et al., 2011).

Approximately $2 \mathrm{~g}$ of freeze-dried sediment was extracted in $8 \mathrm{~mL}$ of a cold solution of methanol, $98 \%$ sulfuric acid and chloroform in the presence of butyl hydroxytoluene (BHT), an antioxidant at a concentration of $50 \mathrm{mg} \mathrm{L}^{-1}$. The ratio of methanol to chloroform to sulfuric acid in the solvent extraction was $1.7: 2: 0.3 v / v / v$. After adding $20 \mu \mathrm{L}$ of the internal standard nonadecanoic acid $\left(1 \mathrm{mg} \mathrm{mL}^{-1}\right)$, samples were placed in a preheated oven (at $90^{\circ} \mathrm{C}$ for $90 \mathrm{~min}$ ) for lipid extraction and methylation of the released fatty acids in fatty acid methyl esters (FAME). Ultra-pure water $(2 \mathrm{~mL})$ was added to each sample to partition the extract in two phases. Following centrifugation ( $5 \mathrm{~min}$ at $1500 \mathrm{rpm}$ and $4{ }^{\circ} \mathrm{C}$ ), the inferior chloroform phase was recovered. A second extraction was made with a solution of hexane and chloroform, $(4: 1 v / v)$ and after centrifugation $(5 \mathrm{~min}$ at $1500 \mathrm{rpm}$ and $\left.4{ }^{\circ} \mathrm{C}\right)$, the superior phase was recovered and added to the first organic phase. This procedure was repeated twice. The organic phases were pooled and cleaned with a cold solution of potassium carbonate ( $2 \%$ ). After centrifugation (5 minutes at $1500 \mathrm{rpm}$ and $4{ }^{\circ} \mathrm{C}$ ), the organic phase was recovered, evaporated to dryness at room temperature, and diluted again with $400 \mu \mathrm{L}$ of pure hexane prior to analysis.

FAME were analysed with a GC coupled to an ion-trap mass spectrometer (MS) GCMS-QP2010. A BPX70 chromatographic column was used. The column had a length of $30 \mathrm{~m}$ and an internal diameter of $0.25 \mathrm{~mm}$; film thickness was $0.25 \mu \mathrm{m}$. The flow was constant with a velocity of $1 \mathrm{~mL} \mathrm{~min}^{-1}$. The injector temperature was set to $260^{\circ} \mathrm{C}$ and the volume injected was $1 \mu \mathrm{L}$. The use of known standards as reference (Supelco 37-component FAME mix) allowed for FA quantification. Data were treated with the GCMSsolution software version 2.5. The peaks of the chromatogram were identified based on FA molecular weights and on their retention times in the chromatographic column.

In order to present the data set in a comprehensible form, fatty acids were grouped according to their chemical structure into (a) polyunsaturated fatty acids (PUFA), compounds with two or more unsaturated bonds; (b) monounsaturated fatty acids (MUFA), compounds with one unsaturation; (c) mid-chain fatty acids (MC-FA), chain length $\leq C_{20}$; and (d) long-chain fatty acids (LC-FA), chain length $C_{21}-C_{26}$.

Concentrations are expressed in $\mathrm{mg} \mathrm{kg}^{-1} \mathrm{DW}$.

\subsubsection{Amino acids}

Total hydrolysable amino acids (THAA) were analysed following the AccQ-Tag method by Waters which utilizes the pre-column derivatization reagent 6-aminoquinolyl-Nhydroxysuccinimidyl carbamate (AQC) to produce fluorescently labelled amino acids for analysis. The Waters AccQTag Fluor derivatization reagent kit, ref: WAT52880, was used. Approximately $15 \mathrm{mg}$ of freeze-dried sediment was submitted to hydrolysis with $250 \mu \mathrm{L}$ of hydrochloric acid $12 \mathrm{~N}$ and $230 \mu \mathrm{L}$ of Milli-Q water at $100^{\circ} \mathrm{C}$ for $24 \mathrm{~h}$ and under vacuum. Together with sediment samples, the internal standard $\alpha$-amino- $n$-butyric acid (AABA) was also submitted to acidic hydrolysis. After the evaporation of the hydrolysate with a rotary evaporator, samples were derivatizated. The hydrolysate was redisolved with $300 \mu \mathrm{L}$ of hydrochloric acid $20 \mathrm{mM}$, filtered with syringe nylon filters (pore diameter $0.45 \mu \mathrm{m}$ ) and buffered with $70 \mu \mathrm{L}$ of a borax buffer solution. The reagent $\mathrm{A}(20 \mu \mathrm{l})$ was then added. After $1 \mathrm{~min}$ at ambient temperature and $10 \mathrm{~min}$ at $55^{\circ} \mathrm{C}$, the solution was mixed with $100 \mu \mathrm{L}$ of the mobile phase and transferred to HPLC vials.

Analyses were carried out with a gradient HPLC Waters 600 coupled with a Waters Delta 600 pump and a Waters 2487 (dual absorbance detector) UV absorption detector (Ex. $250 \mathrm{~nm}$, Em. $395 \mathrm{~nm}$ ). The column was a NOVA-PAK ${ }^{\circledR}$ $C_{18} 4 \mu \mathrm{m} 3.9 \times 150 \mathrm{~mm}$ part no. WAT086344. An automatic injector Waters 717 plus and an in-line degasser AF were utilized. Analyses were carried out at a temperature of $37^{\circ} \mathrm{C}$. The mobile phase consisted of three solutions, A (AccQTag Eluent A), B (acetonitrile) and C (HPLC-grade water). The velocity of the flux was $1 \mathrm{~mL} \mathrm{~min}^{-1}$ and the pressure 
2000 psi. The volume of injection was $20 \mu \mathrm{L}$ and the run time $55 \mathrm{~min}$. The Pierce (Thermo Scientific) Amino Acid Standard $\mathrm{H}, 10 \times 1 \mathrm{~mL}$ (reference 200880) was used.

Data were treated with the JASCO ChromPass chromatography data system software version 1.7.403.1. Two subgroups of THAA, neutral THAA (alanine, valine, isoleucine, leucine and phenylalanine) and protein THAA (aspartic acid, serine, glutamic acid, glycine, histidine, arginine, threonine, alanine, tyrosine, valine, lysine, isoleucine, leucine and phenylalanine) were used as labile organic matter indicators. The aspartic acid (Asp) to $\beta$-alanine (BALA) and the glutamic acid (Glu) to $\gamma$-aminobutyric acid (GABA) ratios were utilized as degradation indexes.

Concentrations are expressed in $\mathrm{nmol} \mathrm{mg}^{-1} \mathrm{DW}$.

\subsubsection{Carbohydrates}

For the analysis of carbohydrates (CHO), sediment samples were prepared following the protocol of Oakes et al. (2010). A volume of $0.5 \mathrm{~mL}$ of concentrated $(11 \mathrm{M})$ sulfuric acid was added to approximately $0.5 \mathrm{~g}$ of freeze-dried sediment. The mixture of sediment and sulfuric acid was mixed with the vortex, and after one hour, $4.5 \mathrm{~mL}$ of Milli-Q water was added to reduce the concentration of sulfuric acid from $11 \mathrm{M}$ to $1 \mathrm{M}$. Samples were then hydrolysed for $1 \mathrm{~h}$ at $120^{\circ} \mathrm{C}$ (the reaction was stopped by placing on ice the Corning Pyrex glass tubes containing the samples). After neutralization with approximately $2 \mathrm{~g}$ of strontium carbonate and centrifugation $(15 \mathrm{~min}$ at $15000 \mathrm{rpm})$, the hydrolysate was transferred to Eppendorf tubes and stored overnight at $-20^{\circ} \mathrm{C}$. Before preparing the HPLC vials, Eppendorf tubes were centrifuged again (15 min at $15000 \mathrm{rpm})$ and the supernatant was filtered with syringe nylon filters (pore diameter $0.45 \mu \mathrm{m}$ ).

Carbohydrates were analysed with a Waters 2695 52C separations module chromatograph coupled with a Waters 2414 refractive index detector (temperature $37^{\circ} \mathrm{C}$ and sensitivity 16). Two columns were utilized: an Aminex HPX-87P $(300 \times 7.8 \mathrm{~mm})$ and an Aminex HPX-87C $(300 \times 7.8 \mathrm{~mm})$. The mobile phase consisted of Milli-Q water. The velocity of the flux was $0.6 \mathrm{~mL} \mathrm{~min} \mathrm{~m}^{-1}$ and the pressure $1700 \mathrm{psi}$. The volume of injection was $100 \mu \mathrm{l}$ and the run time $25 \mathrm{~min}$. Standard reagents of $\mathrm{D}(+)$-glucose anhydrous (reference G8270 Sigma), D(+)-xylose (reference X1500 Sigma), D(+)galactose (reference G-0750 Sigma) and D(+)-mannose (reference 63580 Fluka) were also analysed to obtain quantitative data. Carbohydrate peaks were identified in the chromatogram through their retention times, using the Empower software, specifically for the treatment of chromatographic data.

Due to the low quantity of sediment available from those stations sampled in spring, it has been possible to perform $\mathrm{CHO}$ analyses only on autumn samples.

Concentrations are expressed in $\mathrm{mg} \mathrm{g}^{-1} \mathrm{DW}$.

\section{Statistics}

Univariate and multivariate statistical tests were carried out on all the analysed samples. Data were OC-normalized before performing statistical analysis by dividing the dry weight concentration by the percentage of total organic carbon in the dry weight sample (expressed as a decimal).

Two-way ANOVA comparisons were made to test for differences between spring (SPR) and autumn (AUTM) and between the untrawled and the trawled regions (UTR and TR, respectively), and also to verify if an interaction between the effects of trawling and season on the quality of the organic matter exists. For carbohydrates, due to the absence of spring samples, a one-way ANOVA has been performed instead of the two-way ANOVA. Normality and homogeneity of variances were tested before performing the one-way and two-way ANOVA. Normality was assessed through the Kolmogorov-Smirnov (K-S) test. The null hypothesis of the $\mathrm{K}-\mathrm{S}$ test is that no difference exists between the distribution of the data set and an ideal Gaussian distribution. When the $p$ value of the $\mathrm{K}-\mathrm{S}$ test is lower than 0.05 , the null hypothesis is rejected, meaning that the data did not follow a normal distribution. Measures of shape, like skewness and kurtosis, were also considered, being that a normal distribution is characterized by values of skewness comprised between -0.5 and 0.5 and values of kurtosis approximately equal to 3 . When normality was violated, data were transformed before testing the homogeneity of variances (homoscedasticity). Homoscedasticity was tested though the Hartley $F_{\max }$ test (Hartley, 1950) by dividing the larger variance by the smaller one to obtain the $F$ ratio. An $F$-ratio value close to 1 , or higher than 1 but lower than the value in the $F_{\max }$ table, indicated homogeneity of variance. Since the number of samples was not the same within both the couple of groups compared, the degrees of freedom were calculated considering the higher number of samples for each couple of groups. When there was no normality and/or homogeneity of variance, a more conservative level of significance was considered $(p=0.001)$. Due to the uneven sample size and also to avoid problems related to normality, a generalized linear model (GLM) has been also used to compare results from the two-way ANOVA and the GLM analyses. The one-way ANOVA was performed with the Statistica software v.5.5, whereas the two-way ANOVA and the GLM were performed with the R software version 2.15.2.

Multivariate statistical analyses were also performed. Before multivariate analysis, data were pre-treated by a square root or fourth root transformation to downweight contributions from quantitatively dominant macromolecules. Euclidean distances between pairs of samples were then calculated to obtain a triangular distance matrix. Differences between SPR and AUTM as well as between UTR and TR were tested through the non-parametric analysis of similarities (ANOSIM test). ANOSIM is a resemblance-based permutation method used to test the null hypothesis of "no 
differences" between a priori-defined groups of multivariate samples. Since dissimilarities are not normally distributed, ANOSIM uses ranks of pairwise dissimilarities. The null hypothesis is that the average of rank dissimilarities between objects within groups is equal to the average of rank dissimilarities between objects from different groups. The ANOSIM $\mathrm{R}$ statistic value is used to measure how different two groups are, and it is calculated from the average of rank dissimilarities between objects (by subtracting the average of rank dissimilarities within groups to the average of rank dissimilarities between groups). When $R=0$, inter- and intra-group differences are equal, and when $R<0$, intra-group differences are higher than inter-group differences, whereas when $R>0$, inter-group differences are higher than intra-group differences (Clarke and Gorley, 2001). Primer software v.6 was utilized (Clarke, 1993; Clarke and Gorley, 2006) for multivariate statistical analyses.

The similarity percentages (SIMPER) test was carried out to quantify the contribution of biomarkers to dissimilarities within and between trawling regions and season groups. SIMPER calculates the percentage contribution of each variable (i.e. Chl $a$; MUFA: $16: 1,18: 1 t, 18: 1,18: 1 c, 20: 1$, $22: 1,24: 1$; protein and neutral THAA: Asp, Ser, Glu, Gly, His, Arg, Thr, Ala, Tyr, Val, Lys, Ile, Leu, Phe) to the dissimilarities within each a priori-defined group (i.e. UTR, TR, SPR and AUTM) between regions (UTR and TR) and between sampling seasons (SPR and AUTM). The average square distance is shown together with the percentage contribution of each variable to the average square distance.

Principal components analysis (PCA) was used to identify the best biomarker (among Chl $a, 16: 1,18: 1 t, 18: 1$, $18: 1 c, 20: 1,22: 1,24: 1$, Asp, Ser, Glu, Gly, His, Arg, Thr, Ala, Tyr, Val, Lys, Ile, Leu and Phe) to distinguish between trawling regions and between season groups. The PCA is a multivariate technique used to reduce the multidimensionality which corresponds to the variation of a high number of correlated variables. Multi-dimensionality is reduced to two or three dimensions which correspond to a limited number of uncorrelated components, each of which is a combination of the original variables. The extracted uncorrelated components are called principal components (PC) and are estimated from the correlation matrix of the original variables. The objective of PCA is to reduce dimensionality by extracting the smallest number of components that account for most of the variation in the original multivariate data and to summarize the data with no loss of information. The first PCA accounts for as much of the variation as possible and each successive component accounts for a little less. The eigenvalues measure the amount of the variation explained by each PC and will be largest for the first PC and smaller for the subsequent PCs, whereas the eigenvectors provide the weights to compute the uncorrelated PC.

\section{Results}

Laboratory analysis results are shown in Supplement A, B, C and $\mathrm{D}$, whereas statistical test results are shown in Tables 24. A significant difference between SPR and AUTM was found in the Chl $a$ (SPR: $5.99 \pm 5.93$; AUTM: $1.84 \pm 2.15$ ) (Supplement A1, Table 2c and e) and carotenoid (SPR: $13.47 \pm 7.75$; AUTM: $11.99 \pm 7.44$ ) (Supplement A3 and Table 3) percentages and, as regards Chl $a$ degradation products, in the sum of the percentages of the Chl $a$ degradation products (SPR: 18.22 \pm 11.61 ; AUTM: $23.97 \pm 12.68$ ) (Supplement A2 and Table 3). Based on the results of the twoway ANOVA, the Chl $a$-to-Pheo $a$ ratio also showed significant inter-seasonal differences (SPR: $1.60 \pm 1.86$; AUTM: $0.43 \pm 0.82$ ) (Table $2 \mathrm{c}$ ), with a $p$ value of 0.004 . Nevertheless, neither AUTM nor SPR samples showed a normal distribution (Table 2a), which is one of the assumptions for performing ANOVA. Therefore, we consider instead the results of the GLM, which showed no significant differences in the $\mathrm{Chl} a$-to-Pheo $a$ ratio between seasons (Table 2e). The twoway ANOVA evidenced a lack of interaction between trawling and season both in the case of Chl $a$ and for the Chl $a$-toPheo $a$ ratio (Table 2c).

The total concentration of FA varied from $\sim 1.4 \mathrm{mg}$ $\mathrm{kg}^{-1}$ DW (at NF-3 station, from 4 to $5 \mathrm{~cm}$ depth) to $\sim 43.1 \mathrm{mg} \mathrm{kg}^{-1} \mathrm{DW}$ (at SF-5 station, from 0 to $1 \mathrm{~cm}$ depth) (Supplement B). PUFA and MC-FA concentrations were not significantly different, neither between seasons nor between trawling regions, whereas significant differences in MUFA concentrations were found between SPR and AUTM (Table 3). Also LC-FA concentrations were significantly different between sampling seasons (Table 3 ).

The total concentration of THAA varied from $\sim 11 \mathrm{nmol} \mathrm{mg}^{-1} \mathrm{DW}$ (at NF-4 station, from 3 to $4 \mathrm{~cm}$ depth) to $\sim 32 \mathrm{nmol} \mathrm{mg}^{-1} \mathrm{DW}$ (at SF-3 station, from 2 to $3 \mathrm{~cm}$ depth) (Supplement C). No significant differences in the concentration of total, protein and neutral THAA were found between SPR and AUTM, whereas significant differences between UTR and TR were found in the concentrations of total, protein and neutral THAA (Table 3). No significant differences in the Asp-to-BALA and the Glu-to-GABA ratios were found between SPR and AUTM or between UTR and TR (Table $2 c$ and e). The two-way ANOVA evidenced a lack of interaction between trawling and season both in the case of the Asp-to-BALA ratio and in the case of the Glu-to-GABA ratio (Table 2c).

Carbohydrate results are shown in Supplement D. The total concentration of carbohydrates varied from $\sim 0.3 \mathrm{mg} \mathrm{g}^{-1} \mathrm{DW}$ (at SF-4 station, from 2 to $3 \mathrm{~cm}$ depth) to $\sim 1.1 \mathrm{mg} \mathrm{g}^{-1} \mathrm{DW}$ (at SF-3 station, from 2 to $3 \mathrm{~cm}$ depth) (Supplement D). No significant difference between UTR and TR was found for xylose, rhamnose or for the sum of the labile sugars glucose and mannose (Tables $2 \mathrm{~d}$ and 3 ).

Based on the SIMPER analysis, homogeneity was similar in the untrawled and in the trawled region (average square 
Table 2a. Results of the Kolmogorov-Smirnov test. Normality distributions are marked in bold.

\begin{tabular}{|c|c|c|c|c|c|c|}
\hline \multirow[t]{2}{*}{ Variable } & \multirow[t]{2}{*}{ Transformation } & \multirow{2}{*}{$\begin{array}{c}\mathrm{K}-\mathrm{S} \\
p \text { value }\end{array}$} & \multicolumn{2}{|c|}{ Skewness } & \multicolumn{2}{|c|}{ Kurtosis } \\
\hline & & & Skewness & $\begin{array}{l}\text { Std. Err. } \\
\text { Skewness }\end{array}$ & Kurtosis & $\begin{array}{l}\text { Std. Err. } \\
\text { Kurtosis }\end{array}$ \\
\hline$\%$ Chl $a$ AUTUMN & - & $<0.10$ & 0.953 & 0.403 & -0.246 & 0.788 \\
\hline$\%$ Chl $a$ SPRING & - & $>0.20$ & 0.414 & 0.580 & -1.220 & 1.121 \\
\hline$\%$ Chl $a$ TRAWLED & - & $<0.10$ & 1.341 & 0.427 & 0.914 & 0.833 \\
\hline$\%$ Chl $a$ UNTRAWLED & - & $>0.20$ & 1.161 & 0.524 & 0.364 & 1.014 \\
\hline$\%$ Chl $a$ AUTM trawled & - & $<0.10$ & 0.990 & 0.512 & -0.285 & 0.992 \\
\hline$\%$ Chl $a$ AUTM untrawled & - & $>0.20$ & 0.849 & 0.597 & -0.537 & 1.154 \\
\hline$\%$ Chl $a$ SPR trawled & - & $>0.20$ & 0.022 & 0.687 & -1.741 & 1.334 \\
\hline$\%$ Chl $a$ SPR untrawled & - & $>0.20$ & 0.477 & 0.913 & -3.086 & 2.000 \\
\hline Chl $a$-to-Pheo $a$ ratio AUTUMN & - & $<0.01$ & 2.492 & 0.409 & 5.534 & 0.798 \\
\hline Chl $a$-to-Pheo $a$ ratio SPRING & - & $>0.20$ & 0.991 & 0.580 & -0.300 & 1.121 \\
\hline Chl $a$-to-Pheo $a$ ratio TRAWLED & $\log (x+1)$ & $<0.05$ & 1.248 & 0.427 & 0.166 & 0.833 \\
\hline Chl $a$-to-Pheo $a$ ratio UNTRAWLED & $\log (x+1)$ & $<0.15$ & 1.571 & 0.536 & 1.530 & 1.038 \\
\hline Chl $a$-to-Pheo $a$ ratio AUTM trawled & $\log (x+1)$ & $<0.10$ & 2.061 & 0.512 & 3.495 & 0.992 \\
\hline Chl $a$-to-Pheo $a$ ratio AUTM untrawled & $\log (x+1)$ & $<0.20$ & 1.924 & 0.597 & 3.657 & 1.154 \\
\hline Chl $a$-to-Pheo $a$ ratio SPR trawled & - & $>0.20$ & 1.076 & 0.687 & 0.572 & 1.334 \\
\hline Chl $a$-to-Pheo $a$ ratio SPR untrawled & - & $>0.20$ & 0.733 & 0.913 & -2.262 & 2.000 \\
\hline Asp-to-BALA ratio AUTUMN & - & $>0.20$ & 0.963 & 0.434 & 1.326 & 0.845 \\
\hline Asp-to-BALA ratio SPRING & - & $>0.20$ & 0.542 & 0.661 & 0.364 & 1.279 \\
\hline Asp-to-BALA ratio TRAWLED & - & $>0.20$ & 0.991 & 0.472 & 1.142 & 0.918 \\
\hline Asp-to-BALA ratio UNTRAWLED & - & $>0.20$ & 1.623 & 0.564 & 4.587 & 1.091 \\
\hline Glu-to-GABA ratio AUTUMN & - & $>0.20$ & 1.324 & 0.448 & 1.702 & 0.872 \\
\hline Glu-to-GABA ratio SPRING & - & $>0.20$ & 2.154 & 0.661 & 5.691 & 1.279 \\
\hline Glu-to-GABA ratio TRAWLED & - & $>0.20$ & 1.641 & 0.481 & 3.574 & 0.935 \\
\hline Glu-to-GABA ratio UNTRAWLED & - & $>0.20$ & 1.176 & 0.580 & 0.800 & 1.121 \\
\hline Xylose TRAWLED & - & $>0.20$ & -0.390 & 0.524 & -0.581 & 1.014 \\
\hline Xylose UNTRAWLED & - & $>0.20$ & 1.802 & 0.616 & 3.598 & 1.191 \\
\hline Rhamnose TRAWLED & - & $>0.20$ & 0.238 & 0.524 & 1.379 & 1.014 \\
\hline Rhamnose UNTRAWLED & - & $>0.20$ & -0.168 & 0.616 & -0.164 & 1.191 \\
\hline
\end{tabular}

Table 2b. Results of the Hartley $F_{\max }$ test. Homogeneity of variance is marked in bold. Transformed data are marked with an asterisk.

\begin{tabular}{|c|c|c|c|c|c|c|c|c|c|}
\hline Macromolecule & Differences to test & Indicator & $\begin{array}{r}\text { Variance } \\
\text { AUTM }\end{array}$ & $\begin{array}{r}\text { Variance } \\
\text { SPR }\end{array}$ & $\begin{array}{r}\text { Variance } \\
\text { TRAW }\end{array}$ & $\begin{array}{r}\text { Variance } \\
\text { UNTRAW }\end{array}$ & $F$ ratio & $\mathrm{df}$ & $\begin{array}{l}\text { No. of } \\
\text { groups }\end{array}$ \\
\hline \multirow{8}{*}{ PIGMENTS } & \multirow{2}{*}{ BETWEEN SEASONS } & $\%$ Chlorophyll $a$ & 4.62 & 35.17 & & & 7.61 & 33 & 2 \\
\hline & & Chl $a$-to-Pheo $a$ ratio & 0.67 & 3.46 & & & 5.16 & 32 & 2 \\
\hline & \multirow{6}{*}{$\begin{array}{l}\text { BETWEEN TRAWLING } \\
\text { REGIONS }\end{array}$} & \% Chlorophyll $a$ & & & 23.81 & 6.35 & 3.75 & 29 & 2 \\
\hline & & $\%$ Chl $a$ SPR & & & 44.22 & 13.84 & 3.20 & 9 & 2 \\
\hline & & $\%$ Chl $a$ AUTM & & & 5.66 & 3.46 & 1.64 & 19 & 2 \\
\hline & & Chl $a$-to-Pheo $a$ ratio* & & & 0.0576 & 0.0625 & 1.09 & 29 & 2 \\
\hline & & Chl $a$-to-Pheo $a$ ratio SPR & & & 2.47 & 6.00 & 2.43 & 9 & 2 \\
\hline & & Chl $a$-to-Pheo $a$ ratio AUTM $*$ & & & 0.0361 & 0.0225 & 1.60 & 19 & 2 \\
\hline \multirow{4}{*}{$\begin{array}{l}\text { AMINO } \\
\text { ACIDS }\end{array}$} & \multirow{2}{*}{ BETWEEN SEASONS } & Asp-to-BALA ratio & 68.72 & 15.05 & & & 4.57 & 28 & 2 \\
\hline & & Glu-to-GABA ratio & 78.68 & 62.09 & & & 1.27 & 26 & 2 \\
\hline & BETWEEN TRAWLING & Asp-to-BALA ratio & & & 47.20 & 69.56 & 1.47 & 23 & 2 \\
\hline & REGIONS & Glu-to-GABA ratio & & & 55.65 & 105.88 & 1.90 & 22 & 2 \\
\hline CARBO- & BETWEEN TRAWLING & Xylose & & & 9.852 & 70.232 & 7.13 & 18 & 2 \\
\hline HYDRATES & REGIONS & Rhamnose & & & 103.665 & 230.600 & 2.23 & 18 & 2 \\
\hline
\end{tabular}

distance: 18.31 and 21.12, respectively), and amino acids (total, protein and neutral THAA) contributed with low percentages to the average square distance within UTR and TR (Ta- ble 4a). Homogeneity was similar also in AUTM and in SPR (average square distance: 20.77 and 17.76, respectively), and in both cases, Chl $a$ and MUFA showed low contributions 
Table 2c. Results of the statistical test two-way ANOVA for pigments (Chl $a$ and Chl $a$-to-Pheo $a$ ratio) amino acids (Asp-to-BALA and Glu-to-GABA ratios) and carbohydrates (xylose and rhamnose). Significant differences are in bold.

\begin{tabular}{llrrrrr}
\hline Indicator & Effect to test & DF & SS & MS & $F$ value & $\operatorname{Pr}(>F)$ \\
\hline \multirow{5}{*}{ Chl $a$} & TRAWLING & 1 & 23.8 & 23.85 & 1.803 & 0.18547 \\
& SEASON & $\mathbf{1}$ & $\mathbf{1 4 9 . 6}$ & $\mathbf{1 4 9 . 5 7}$ & $\mathbf{1 1 . 3 0 6}$ & $\mathbf{0 . 0 0 1 4 9}$ \\
& TRAWLING : SEASON & 1 & 13.2 & 13.18 & 0.997 & 0.32294 \\
& Residuals & 50 & 661.5 & 13.23 & & \\
\hline \multirow{5}{*}{ Chl $a$-to-Pheo $a$ ratio } & TRAWLING & 1 & 0.24 & 0.238 & 0.155 & 0.69613 \\
& SEASON & $\mathbf{1}$ & $\mathbf{1 4 . 3 9}$ & $\mathbf{1 4 . 3 9 3}$ & $\mathbf{9 . 3 5 1}$ & $\mathbf{0 . 0 0 3 7 8}$ \\
& TRAWLING : SEASON & 1 & 1.65 & 1.653 & 1.074 & 0.30577 \\
& Residuals & 44 & 67.72 & 1.539 & & \\
\hline \multirow{5}{*}{ Asp-to-BALA ratio } & TRAWLING & 1 & 20.0 & 20.01 & 0.350 & 0.558 \\
& SEASON & 1 & 68.7 & 68.71 & 1.201 & 0.280 \\
& TRAWLING : SEASON & 1 & 1.6 & 1.59 & 0.028 & 0.869 \\
& Residuals & 36 & 2059.2 & 57.20 & & \\
\hline \multirow{5}{*}{ Glu-to-GABA ratio } & TRAWLING & 1 & 55.3 & 55.33 & 0.738 & 0.396 \\
& SEASON & 1 & 89.6 & 89.56 & 1.195 & 0.282 \\
& TRAWLING : SEASON & 1 & 69.6 & 69.56 & 0.928 & 0.342 \\
& Residuals & 34 & 2548.8 & 74.97 & & \\
\hline
\end{tabular}

DF: degrees of freedom; SS: sum of squares; MS: mean squares, obtained dividing the sum of squares by the degrees of freedom; $F$ represents the result of the $F$ test and is obtained dividing the mean squares of the inter-group variability by the mean squares of the intra-group variability.

Table 2d. Results of the statistical test one-way ANOVA for carbohydrates (xylose and rhamnose). Significant differences are in bold.

\begin{tabular}{|c|c|c|c|c|c|c|c|c|}
\hline Macromolecule & Differences to test & Indicator & Variability & SS & DF & MS & $F$ & $p$ value \\
\hline \multirow{2}{*}{ CARBOHYDRATES } & \multirow{2}{*}{$\begin{array}{l}\text { BETWEEN TRAWLING } \\
\text { REGIONS }\end{array}$} & Xylose & $\begin{array}{l}\text { Inter } \\
\text { Intra }\end{array}$ & $\begin{array}{r}80.775 \\
1020.122\end{array}$ & $\begin{array}{r}1 \\
30\end{array}$ & $\begin{array}{l}80.775 \\
34.004\end{array}$ & 2.376 & 0.134 \\
\hline & & Rhamnose & $\begin{array}{l}\text { Inter } \\
\text { Intra }\end{array}$ & $\begin{array}{r}5.485 \\
4633.175\end{array}$ & $\begin{array}{r}1 \\
30\end{array}$ & $\begin{array}{r}5.485 \\
154.439\end{array}$ & 0.036 & 0.852 \\
\hline
\end{tabular}

DF: degrees of freedom; SS: sum of squares; MS: mean squares, obtained dividing the sum of squares by the degrees of freedom; $F$ represents the result of the $F$ test and is obtained dividing the mean squares of the inter-group variability by the mean squares of the intra-group variability.

Table 2e. Results of the generalized linear model (GLM) for pigments (Chl $a$ and Chl $a$-to-Pheo $a$ ratio) and amino acids (Asp-to-BALA and Glu-to-GABA ratios).

\begin{tabular}{|c|c|c|c|c|c|c|c|c|c|c|}
\hline \multirow[t]{2}{*}{ Formula } & \multicolumn{5}{|c|}{ Deviance residuals } & & \multicolumn{4}{|c|}{ Coefficients } \\
\hline & Min & $1 \mathrm{Q}$ & Median & $3 \mathrm{Q}$ & Max & & Estimate & Std. Error & $t$ value & $\operatorname{Pr}(>|t|)$ \\
\hline \multirow{4}{*}{ ASPBALA TRAWLING $\times$ SEASON } & \multirow{4}{*}{-12.8018} & \multirow{4}{*}{-4.3935} & \multirow{4}{*}{-0.9087} & \multirow{4}{*}{3.0020} & \multirow{4}{*}{23.5412} & (Intercept) & 24.4198 & 1.7826 & 13.699 & $7.55 \times 10^{-16}$ \\
\hline & & & & & & TRAWLING & -1.0020 & 2.8945 & -0.346 & 0.731 \\
\hline & & & & & & SEASON & -2.5512 & 3.5653 & -0.716 & 0.479 \\
\hline & & & & & & TRAWLING : SEASON & -0.9029 & 5.4177 & -0.167 & 0.869 \\
\hline \multirow{4}{*}{ GLUGABA $\sim$ TRAWLING $\times$ SEASON } & \multirow{4}{*}{-10.764} & \multirow{4}{*}{-5.959} & \multirow{4}{*}{-2.076} & \multirow{4}{*}{3.256} & \multirow{4}{*}{24.007} & (Intercept) & 11.5215 & 2.1646 & 5.323 & $6.54 \times 10^{-6}$ \\
\hline & & & & & & TRAWLING & 0.6098 & 3.3912 & 0.180 & 0.858 \\
\hline & & & & & & SEASON & -5.7052 & 3.9236 & -1.454 & 0.155 \\
\hline & & & & & & TRAWLING : SEASON & 6.1644 & 6.3993 & 0.963 & 0.342 \\
\hline \multirow{4}{*}{ CHLA $\sim$ TRAWLING $\times$ SEASON } & \multirow{4}{*}{-6.0580} & \multirow{4}{*}{-1.8845} & \multirow{4}{*}{-0.8236} & \multirow{4}{*}{2.0574} & \multirow{4}{*}{11.1820} & (Intercept) & 1.8845 & 0.8133 & 2.317 & 0.0246 \\
\hline & & & & & & TRAWLING & -0.1059 & 1.2675 & -0.084 & 0.9337 \\
\hline & & & & & & SEASON & 4.1735 & 1.2424 & 3.359 & 0.0015 \\
\hline & & & & & & TRAWLING : SEASON & -2.2621 & 2.2659 & -0.998 & 0.3229 \\
\hline \multirow{4}{*}{ ChlPheoRATIO $\sim$ TRAWLING $\times$ SEASON } & \multirow{4}{*}{-2.1306} & \multirow{4}{*}{-0.4409} & \multirow{4}{*}{-0.3827} & \multirow{4}{*}{0.1495} & \multirow{4}{*}{3.3054} & (Intercept) & 0.44095 & 0.27741 & 1.589 & 0.1191 \\
\hline & & & & & & TRAWLING & -0.03857 & 0.44199 & -0.087 & 0.9309 \\
\hline & & & & & & SEASON & 0.88825 & 0.48050 & 1.849 & 0.0712 \\
\hline & & & & & & TRAWLING : SEASON & 0.83997 & 0.81062 & 1.036 & 0.3058 \\
\hline
\end{tabular}


Table 3. Results of the multivariate statistical test ANOSIM for pigments (Chl $a$ degradation products and carotenoids), fatty acids (PUFA, MUFA, MC-FA and LC-FA) amino acids (total THAA, protein THAA and neutral THAA) and carbohydrates (sum of glucose and mannose). Significant differences are shown in bold.

\begin{tabular}{|c|c|c|c|c|c|}
\hline Macromolecule & Differences to test & Transformation & Indicator & Global R & $\mathrm{P}$ \\
\hline \multirow{4}{*}{ PIGMENTS } & \multirow{2}{*}{ BETWEEN SEASONS } & Square root & $\%$ Chl $a$ degradation products & 0.212 & 0.002 \\
\hline & & Square root & $\%$ Carotenoids & 0.194 & 0.004 \\
\hline & \multirow{2}{*}{ BETWEEN TRAWLING REGIONS } & Square root & $\%$ Chl $a$ degradation products & 0.036 & 0.199 \\
\hline & & Square root & $\%$ Carotenoids & -0.043 & 0.862 \\
\hline \multirow{8}{*}{ FATTY ACIDS } & \multirow{4}{*}{ BETWEEN SEASONS } & Fourth root & PUFA & 0.063 & 0.085 \\
\hline & & Square root & MUFA & 0.792 & 0.001 \\
\hline & & Square root & MC-FA & -0.028 & 0.584 \\
\hline & & Square root & LC-FA & 0.427 & 0.001 \\
\hline & \multirow{4}{*}{ BETWEEN TRAWLING REGIONS } & Fourth root & PUFA & 0.039 & 0.140 \\
\hline & & Square root & MUFA & 0.067 & 0.078 \\
\hline & & Square root & MC-FA & -0.011 & 0.530 \\
\hline & & Square root & LC-FA & -0.044 & 0.829 \\
\hline \multirow{6}{*}{ AMINO ACIDS } & \multirow{3}{*}{ BETWEEN SEASONS } & Square root & TOTAL THAA & -0.076 & 0.920 \\
\hline & & Square root & PROTEIN THAA & -0.077 & 0.919 \\
\hline & & Square root & NEUTRAL THAA & 0.001 & 0.447 \\
\hline & \multirow{3}{*}{ BETWEEN TRAWLING REGIONS } & Square root & TOTAL THAA & 0.409 & 0.001 \\
\hline & & Square root & PROTEIN THAA & 0.272 & 0.001 \\
\hline & & Square root & NEUTRAL THAA & 0.260 & 0.001 \\
\hline CARBOHYDRATES & BETWEEN TRAWLING REGIONS & Square root & GLUCOSE + MANNOSE & -0.020 & 0.576 \\
\hline
\end{tabular}

to the intra-group distances (Table 4a). Inter-group distances were higher than intra-group distances (Table $4 \mathrm{a}$ and b). Similar average square distances were found between UTR and TR (average square distance: 47.54) and between SPR and AUTM (average square distance: 48.47) (Table 4b). Based on the intra-group distances, as expected, amino acids contribute with high percentages to the average square distance between UTR and TR, whereas the contribution of Chl $a$ and MUFA was high in the case of the seasonal inter-group distances (Table 4b).

Based on the PCA, PC1 accounts for the $27.4 \%$ of the total variation and explains the distribution of total, protein and neutral THAA between trawling regions (Fig. 2a), whereas PC2 accounts for the $17.4 \%$ of the total variation and explains the distribution of Chl $a$ and MUFA between sampling seasons (Fig. 2b).

\section{Discussion}

The main objective of this study is to characterize the organic matter $(\mathrm{OM})$ present in sediments from two regions of a submarine canyon that are affected and unaffected by bottom trawling. We found substantial differences in the quality of the organic matter between these two regions. In particular, the organic matter was more degraded in the trawled than in the untrawled region.
In the sediment column, OM preservation is controlled by several interrelated factors, including oxygen penetration, bioturbation, sediment density and grain size. The monomeric components of biomolecules degrade at similar rates under oxic and anoxic conditions (Henrichs and Doyle, 1986), but macrobiomolecule degradation is faster in oxic conditions than in anoxic compact sediments, where benthic organisms cannot survive and cannot participate, together with bacteria, in OM degradation (Sun et al., 1993; Bianchi et al., 2000). Also protozoa, like benthic organisms, need oxygen to survive, contributing to the higher degradation rates measured in oxic than in anoxic sediments (Williams, 1981).

It has been stated that bottom trawling affects the physical properties of the seafloor, altering grain-size distributions and sediment porosity (Jones, 1992; McConnaughey et al., 2000, and references therein). In addition, the pulling of the bottom trawl gears along the seafloor is deemed responsible for resuspension of surface sediment, which is in this way oxygenated and may lose its finest fraction (Palanques et al., 2001). By removing bioturbators and at the same time artificially mixing sediments, bottom fishing gear is expected to deeply affect benthic community composition and metabolism and hence the biogeochemical characteristics of the affected sediments (Duplisea et al., 2001, and references therein). These environmental factors influence OM preservation and can be responsible for making trawling regions different in terms of the quality of the OM present in the 

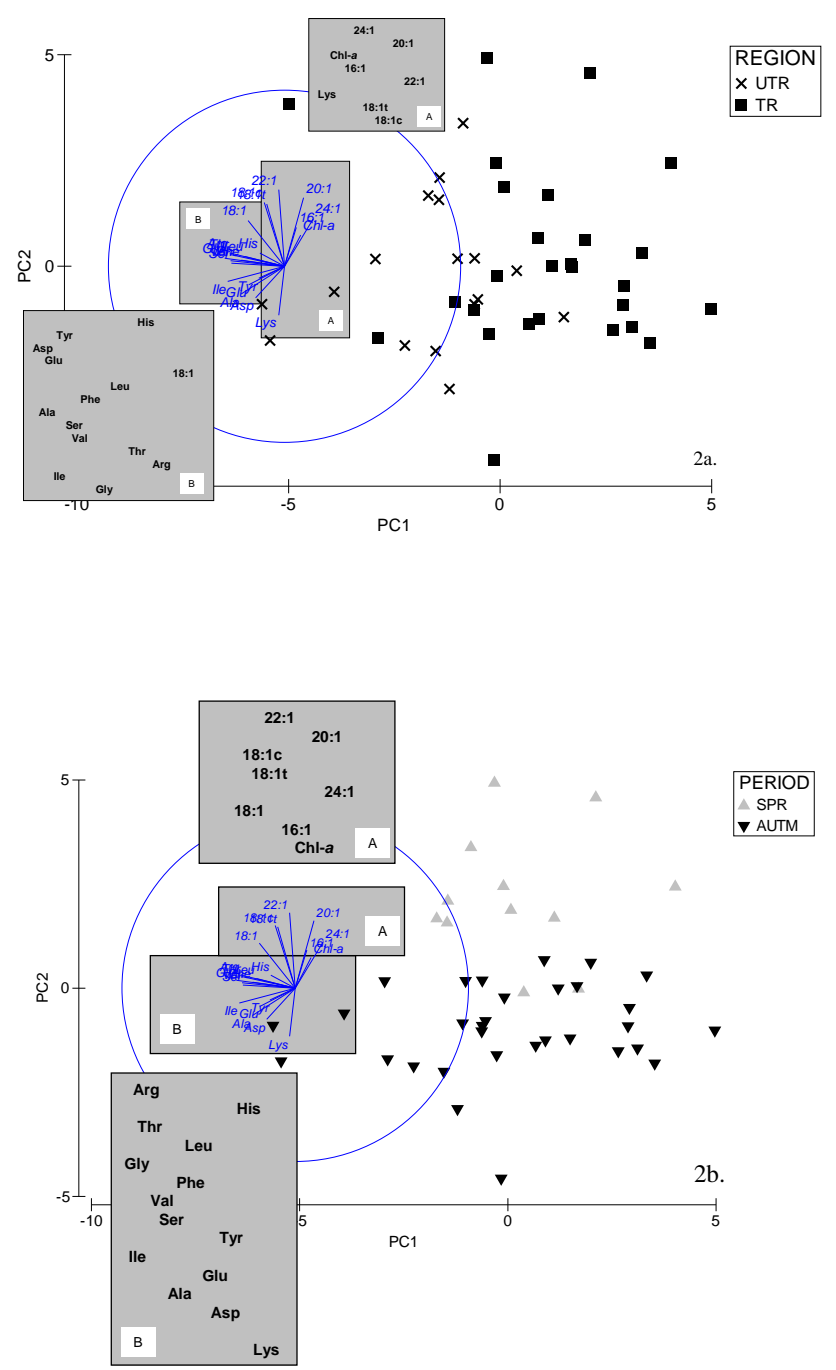

Fig. 2. Representation of the multivariate statistical test PCA carried out on those biomarkers which better evidenced differences between sampling seasons (Chl $a$ and MUFA) and between trawled and untrawled regions (protein and neutral THAA). In (a), stations located in the untrawled and the trawled regions are evidenced, whereas in (b), stations are distinguished based on the sampling season - spring or autumn. Biomarkers are shown in both plots (a) and (b).

sediment column. To study the effects of chronic trawling disturbance, we will now discuss the results obtained from the analysis of several groups of biomarkers, describing the information associated with each of them.

\subsection{Pigments}

The distribution of Chl $a$ in SPR and AUTM samples (Fig. 2b) suggests that this pigment, which is present in all photosynthetic algae and higher plants, can be used as an indicator of the seasonal fresh OM input to the seafloor also in the trawled submarine canyon flanks. In spring, high per- centages of Chl $a$ were found not only at UTR but also at TR (Supplement A1), indicating that the information associated with this tracer (presence of very fresh OM; Wakeham et al., 1997) is prevalent in the entire study area and hence not masked by the long-terms effects of bottom trawling. This agrees with previous work carried out in the southwestern canyons of the Gulf of Lion, in which high quantities of fresh organic matter were found in spring sediment trap samples (Pasqual et al., 2011). In contrast, no significant differences in the Chl $a$ percentage were observed between UTR and TR (Table $2 \mathrm{c}$ and e). The highly labile Chl $a$ biomarker is useful for detecting the subtle OM quality differences between SPR and AUTM sediments but probably too sensitive for evidencing alterations in the quality OM related to trawling activities.

Chl $a$ is degraded to Pheo $a$ by loss of $\mathrm{Mg}$; to pyropheophorbide $a$ by loss of $\mathrm{Mg}$, the phytyl chain and carbomethoxy; and to pheophorbide $a$ by loss of the phytyl chain and oxidation (Louda et al., 2008). Chl $a$ degradation products can be used as OM quality indicators (Lee et al., 2000), such as the Chl $a$-to-Pheo $a$ ratio and the sum of the Chl $a$ degradation products (Lee et al., 2004). However, when using these pigment degradation indexes, it should be considered that the formation of such degradation products depends not only on those environmental factors which enhance Chl $a$ degradation but also on the initial concentration of Chl $a$. Low percentages of pheophytin $a$, pyropheophorbide $a$ and pheophorbide $a$ can be related to Chl $a$ preservation and/or to an initial low availability of Chl $a$. In spite of these considerations, the $\mathrm{Chl} a$ degradation products confirmed the presence of fresher OM in spring than in autumn samples (Table 3) suggested by the Chl $a$ (Table 2c and e).

Another group of pigments is represented by carotenoids, which are characterized by a higher stability than chlorophylls (Reuss, 2005) and may represent the majority of pigments in sediment samples (Repeta and Gagosian, 1987). The distribution of carotenoid percentages in this study suggested higher amounts of refractory OM in spring than in autumn (Supplement A3 and Table 3), but this must be interpreted with caution. In the study area, the relevance of lateral transport of particulate matter (Martín et al., 2006) could mask the signal of the vertical deposition of refractory OM particles onto the seafloor. Labile compounds are also laterally transported, but since they degrade with time, once they settle on the seafloor it is possible to distinguish between the fresh forms, representative of the vertical component of the OM input, and the degraded forms, which are the result of degradation processes during lateral transport. In addition, the presence of carotenoids is not influenced by those environmental factors related to trawling or seasonality which influence the biochemical quality of sediments, and therefore their distribution in the study area cannot help us understanding the effects of these two external factors. 
Table 4a. Results of the multivariate statistical test SIMPER carried out on those biomarkers which better evidenced differences between sampling seasons (Chl $a$ and MUFA) and between trawling regions (protein and neutral THAA). Intra-group distances within the a prioridefined groups UTR, TR, SPR and AUTM.

\begin{tabular}{|c|c|c|c|c|}
\hline \multirow{3}{*}{$\begin{array}{l}\text { Group } \\
\text { Average square distance }\end{array}$} & \multicolumn{4}{|c|}{ INTRA-GROUP DISTANCES } \\
\hline & UTR & TR & SPR & AUTM \\
\hline & 18.31 & 21.12 & 17.76 & 20.77 \\
\hline \multirow{21}{*}{ Variable contribution (\%) } & Tyr (14.12) & Thr (6.05) & Leu $(6.86)$ & $\operatorname{Thr}(5.83)$ \\
\hline & Leu $(9.11)$ & Chl $a(5.95)$ & $18: 1 c(6.73)$ & $16: 1(5.71)$ \\
\hline & Phe (7.57) & $18: 1 t(5.88)$ & Phe (6.59) & Gly (5.45) \\
\hline & Val (7.34) & Ala (5.75) & $\operatorname{Val}(6.21)$ & His (5.34) \\
\hline & $20: 1(6.62)$ & His (5.69) & $22: 1(6.14)$ & Asp (5.26) \\
\hline & $18: 1 c(5.40)$ & $16: 1(5.56)$ & Ala $(5.81)$ & $\operatorname{Ser}(5.19)$ \\
\hline & $24: 1(4.88)$ & $22: 1(5.41)$ & Glu (5.30) & $\operatorname{Arg}(5.12)$ \\
\hline & $22: 1(4.42)$ & $18: 1(5.34)$ & $\operatorname{Arg}(5.07)$ & Glu (5.09) \\
\hline & $16: 1(4.27)$ & Lys (5.30) & $\operatorname{Ser}(4.93)$ & Ile $(5.01)$ \\
\hline & $\operatorname{Asp}(4.21)$ & Ile $(5.29)$ & Ile $(4.58)$ & Lys (4.83) \\
\hline & Lys (4.10) & Gly (5.09) & His (4.49) & Val (4.75) \\
\hline & Gly (4.10) & $\operatorname{Arg}(4.90)$ & Gly (4.17) & Ala (4.68) \\
\hline & His (3.91) & $\operatorname{Asp}(4.15)$ & Asp (4.09) & $24: 1$ (4.65) \\
\hline & Arg (3.73) & $18: 1 c(4.15)$ & $20: 1$ (4.06) & Phe (4.63) \\
\hline & Chl $a$ (3.49) & $24: 1(3.92)$ & $24: 1(4.03)$ & Leu (4.55) \\
\hline & Glu (3.28) & Phe (3.70) & $16: 1(3.29)$ & $18: 1(4.52)$ \\
\hline & $18: 1(2.67)$ & $20: 1(3.53)$ & $\operatorname{Thr}(2.79)$ & $20: 1(3.70)$ \\
\hline & Ile $(2.35)$ & Glu (3.29) & Lys (2.44) & $18: 1 t(3.69)$ \\
\hline & $18: 1 t(2.22)$ & Leu (2.78) & $18: 1 t(2.29)$ & Chl $a(2.94)$ \\
\hline & Ser (1.13) & Val (1.97) & $18: 1(1.00)$ & $18: 1 c(1.67)$ \\
\hline & Thr (0.94) & Tyr (0.00) & Tyr (0.01) & $22: 1(0.54)$ \\
\hline
\end{tabular}

Table 4b. Inter-group distances between UTR and TR and between SPR and AUTM.

\begin{tabular}{|c|c|c|}
\hline & \multicolumn{2}{|c|}{ INTER-GROUP DISTANCES } \\
\hline $\begin{array}{l}\text { Groups } \\
\text { Average square distance }\end{array}$ & $\begin{array}{l}\text { UTR and TR } \\
\mathbf{4 7 . 5 4}\end{array}$ & $\begin{array}{l}\text { SPR and AUTM } \\
\mathbf{4 8 . 4 7}\end{array}$ \\
\hline Variable contribution $(\%)$ & 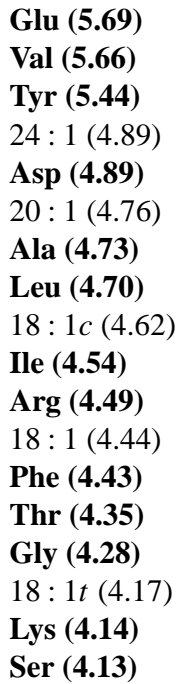 & $\begin{array}{l}\mathbf{2 2}: \mathbf{1}(\mathbf{8 . 2 8}) \\
\mathbf{1 8}: \mathbf{1} \boldsymbol{c}(\mathbf{7 . 0 8}) \\
\mathbf{1 8}: \mathbf{1} \boldsymbol{t}(\mathbf{5 . 7 1}) \\
\text { Chl } \boldsymbol{a} \mathbf{( 5 . 4 8 )} \\
\mathbf{2 0 : 1} \mathbf{( 5 . 4 6 )} \\
\mathbf{1 8}: \mathbf{1}(\mathbf{5 . 0 7}) \\
\text { Lys }(4.56) \\
\mathbf{2 4}: \mathbf{1}(\mathbf{4 . 5 1 )} \\
\text { Ala }(4.24) \\
\text { Leu }(4.21) \\
\text { Phe }(4.17) \\
\text { Val }(4.11) \\
\text { Ile }(4.08) \\
\text { Glu }(3.90) \\
\text { Arg }(3.90) \\
\text { Asp (3.90) } \\
\text { Ser }(3.85) \\
\text { His }(3.76)\end{array}$ \\
\hline
\end{tabular}

\subsection{Fatty acids}

Like Chl $a$, also the labile monounsaturated fatty acids (MUFA) indicated an efficient input of fresh OM (Haddad et al., 1992) to the seafloor following the spring phytoplankton bloom. The lack of significant differences in the concentration of polyunsaturated fatty acids (PUFA) between SPR and AUTM samples (Table 3) may be related to the low number of PUFA compounds found in the study area (only two: FA $22: 2$ and FA $22: 6$; see Supplement B1), which indicates a rapid degradation of this labile group of FA before accumulating in the sediment column (Haddad et al., 1992; Sun and Wakeham, 1994). The degradation of FA, aliphatic hydrocarbon chains with a carboxylic group at one extremity, is selective and depends on the number of carbons and double bonds of the chain. PUFA, FA with a high number of double bonds, represent the most labile group of FA, and their low concentration even in SPR, when high Chl $a$ percentages and MUFA concentrations were found (Supplement A1 and B2), suggests a prior degradation in the water column and/or after deposition on the seafloor (Sun et al., 1997; Wakeham et al., 1997). The selective degradation of PUFA can be particularly intense at the sediment-water interface (Laureillard et al., 1997) and prevents their use as tracers of fresh OM in this region. 
Mid- and long-chain FA (MC-FA and LC-FA, respectively) represent the most refractory fatty acid groups. MCFA did not evidence differences in the quality of the OM in the study area, neither between seasons nor between trawled/untrawled regions, whereas LC-FA evidenced seasonal differences (Table 3). Nevertheless, the distribution of LC-FA in the study area suggested high quantities of refractory material in spring. This further limits the utility of refractory compounds (i.e. carotenoids, MC-FA and LC-FA) as biomarkers in the present study.

To summarize, the fatty acid group includes compounds characterized by a wide range of different labilities. Depending on its lability, each compound behaves in a different way (Fig. 3). At the two extremes, the FA with highest (PUFA) and lowest lability (MC-FA and LC-FA) did not trace differences in the quality of the OM, neither between seasons nor between trawling regions. PUFA are too labile and probably degrade before accumulating in the sediment column, whereas MC-FA and LC-FA are too refractory to be used as biomarkers. MUFA are able to detect differences between sampling seasons.

\subsection{Amino acids}

Like the other macromolecules studied, also amino acids are partially degraded in the water column, but a fraction of the amino acid pool reaches the seafloor and is incorporated in the sediment column (Wakeham et al., 1997; Moore et al., 2012), allowing for the use of these compounds as biomarkers of the quality of the OM. When compared with other results from the NW Mediterranean continental shelf at $\sim 300 \mathrm{~m}$ depth (Grémare et al., 2002, 2005), THAA showed relatively high values in the study area, which can be related to the high downward flux of biogenic particles in La Fonera Canyon (Martín et al., 2006). Amino acids are also considered fresh OM indicators (Lee et al., 2004) and the distribution of THAA values in the study area, with higher mean concentrations in the control area $\left(\sim 22 \pm 3 \mathrm{nmol} \mathrm{mg}^{-1} \mathrm{DW}\right)$ than in the trawled area $\left(\sim 17 \pm 4 \mathrm{nmol} \mathrm{mg}^{-1} \mathrm{DW}\right)$, confirmed the presence of more labile material at UTR (Fig. 2a), as previously suggested by MUFA biomarkers. Statistical tests indicated a clear separation between trawled regions when using THAA as biomarkers, more evident than the separation observed with MUFA as tracers (Table 3). The presence of more labile OM in the untrawled than in the trawled region is evidenced also by the distribution of neutral and protein THAA (Fig. 2a). Neutral THAA are not adsorbed onto clay minerals and are more susceptible to degradation than charged ones. Regarding protein THAA, their concentrations depend on the phytoplanktonic production and, like neutral THAA, can be used as fresh OM indicators. Other THAA - like $\beta$-alanine (BALA), which originates from aspartic acid (Asp), and $\gamma$-aminobutyric acid (GABA), which originates from glutamic acid (Glu) - are associated with degradation processes and may be used as degradation in-

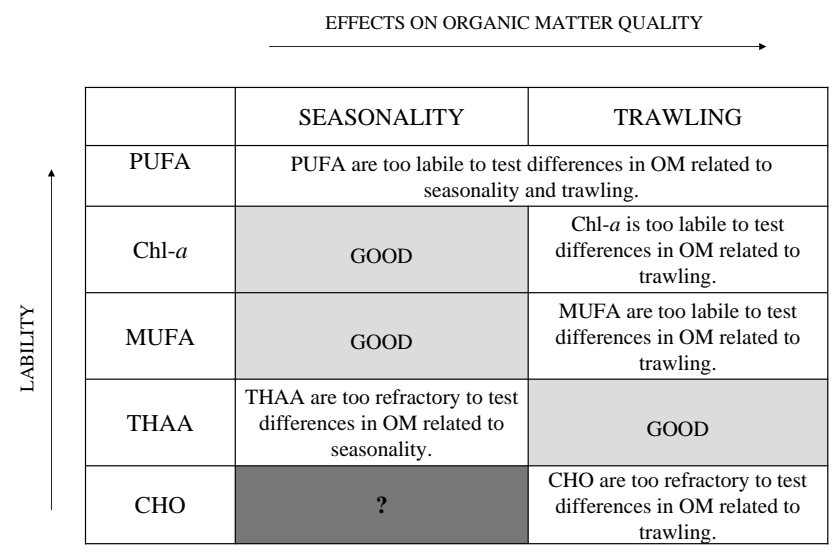

Fig. 3. Schematic representation of the results obtained in this study by using a pool of biomarkers with different lability to investigate on the effects of seasonality and sediment reworking by trawling on the quality of the OM. Due to the unavailability of spring samples, we did not test differences in $\mathrm{CHO}$ between seasons.

dexes (Ingalls et al., 2003), but the absence of significant differences in the Asp-to-BALA and Glu-to-GABA ratios between UTR and TR (Table $2 \mathrm{c}$ and e) supports the doubts expressed by other authors on the validity of these ratios as OM quality indicators (García and Thomsen, 2008). The different degradation pathways and/or rates of Asp and Glu to BALA and GABA, respectively, can be responsible for the inconsistence of the Asp-to-BALA and Glu-to-GABA ratios as organic matter degradation indexes (Lee et al., 2000).

Based on the distribution of THAA in the trawled areas, we might expect higher concentrations of neutral and protein THAA in SPR than in AUTM samples. Nevertheless, no differences were found in the distribution of these THAA indicators between spring and autumn sediments (Table 3). Amino acids are considered less susceptible to degradation than Chl $a$ and MUFA (Wakeham et al., 1997) and this characteristic could make them less adequate than the other two biomarkers for tracing seasonal differences in the nutritional quality of the sedimentary OM. As mentioned before, based on our results, we hypothesize differences in the "freshness" of the OM related to seasonality to be subtle and for this reason detectable by very labile and sensitive OM indicators like $\mathrm{Chl} a$ and MUFA but not by less reactive biomarkers like amino acids (Fig. 3).

\subsection{Carbohydrates}

The absence of significant differences between UTR and TR in the concentration of the labile sugars xylose (Opsahl and Benner, 1999), glucose (Hedges et al., 1988; Hofmann et al., 2009) and mannose (Kerhervé et al., 2002) (Table 3) can be related to the low lability of these compounds if compared with that of MUFA or THAA. In spite of the relative lability of xylose, glucose and mannose, $\mathrm{CHO}$ compounds are in fact considered macromolecules with a low nutritional 
quality (Handa and Tominaga, 1969), characteristic of regions where the supply of fresh OM is limited, like deepsea habitats (Danovaro et al., 1993) and oligotrophic environments (Rodil et al., 2007), and more resistant to degradation than pigments, fatty acids and amino acids (Wakeham et al., 1997). In fact, carbohydrates did not detect differences among trawled and control areas. The possible seasonal influence on carbohydrate distribution could not be assessed due to the fact that only autumn samples were available.

\subsection{Organic matter differences between trawled and untrawled regions}

As expected, environmental factors related to the stirring and resuspension of sediments caused by the passage of bottom trawl gears, such as deepening of the oxygen penetration depth or the loss of the sediment finest fraction (Jones, 1992; McConnaughey et al., 2000; Palanques et al., 2001), do not favour the preservation of organic matter, making trawled regions different in terms of the quality of the organic matter present in the sediment column. Our hypothesis that fresher organic matter would be present in the untrawled rather than in the trawled region was confirmed. Nevertheless, as expected, only some of the analysed compounds provided good evidence of this hypothesis. The best biomarker in this geographical region to trace the effects of sediments reworking by trawling on the biochemical quality of sediments was represented by amino acids (Table $4 \mathrm{~b}$ ). The higher concentrations of total, neutral and protein THAA found in the untrawled than in the trawled region were supported by multivariate statistical tests like ANOSIM (Table 3) and PCA (Fig. 2a).

The use of four groups of biomarkers differently susceptible to degradation also allowed for us to gain qualitative information about the potential effects of trawling on the quality of the OM. The similar behaviour of Chl $a$ and MUFA which appeared as good biomarkers for seasonality but too labile to trace differences in the quality of the OM related to long-term chronic perturbations such as bottom trawling, and the opposite behaviour of the less labile THAA, which appeared better suited to trace changes associated with trawling but were too refractory to trace differences related to seasonality - suggested that the impact exerted by trawling on the biochemical composition of sediments is higher than the natural variation related to seasonality (Table $4 \mathrm{~b}$ and Fig. 3).

Since deep-sea trawling is not exclusive to the study area but widely extended throughout the world's oceans (Bensch et al., 2009; Puig et al., 2012), our results suggest that commercial bottom trawling may have produced changes in the nutritional quality of deep-sea sediments at large spatial scales.

\section{Conclusions}

Bottom trawling in the flanks of La Fonera Canyon has caused an alteration of the quality of the organic matter in surface sediments (upper $5 \mathrm{~cm}$ ), as has been evidenced by the distribution of amino acids in the study area, which can be interpreted as the result of sediment reworking caused by repeated bottom trawling in the northern flank and in the inshore southern flank of the canyon.

The fact that differences between spring and autumn sediments were detected by the most labile biomarkers, Chl $a$ and MUFA, together with the high percentage contribution to the average square distance between SPR and AUTM for Chl $a$ and MUFA, as well as the high percentage contribution to the average square distance between UTR and TR for the majority of amino acids, suggests that alterations in the quality of the organic matter caused by trawling can be considered relatively high if compared with the effects of seasonality. Nutritional value of sedimentary organic matter is crucial for benthic communities; therefore, the changes produced by repeated trawling might imply profound changes on the ecosystem as a whole.

\section{Supplementary material related to this article is available online at http://www.biogeosciences.net/10/ 8093/2013/bg-10-8093-2013-supplement.pdf.}

Acknowledgements. We are grateful to the officers and crew of the RV García del Cid and all the participants in oceanographic cruises HERMIONE I and II for their help at sea. We thank in particular Silvia Bianchelli, not only for her help at sea but also for offering us sediment samples from the HERMIONE I cruise. We also would like to thank L. Berdié, I. Casals, E. del Álamo Acarreta, E. Miralles, V. Ruíz-Calero and P. Teixidor for their help in the laboratory at the Barcelona Science Park. We are also very grateful to Samuele Tecchio for his valuable help in the statistical analysis of the data. VMS data shown in Figure 1 were provided by the Spanish General Secretariat of Maritime Fishing (SEGEMAR). The research leading to these results has received funding from the European Community's Seventh Framework Programme (FP7/2007-2013) under the HERMIONE project, grant agreement no. 226354, and from a complementary action of the Spanish National Plan (ref. CTM2010-11084-E). J. Martín was funded through a JAE-DOC contract within the programme "Junta para la Ampliación de Estudios", granted by Consejo Superior de Investigaciones Científicas and co-financed by the European Social Fund.

Edited by: J. Middelburg 


\section{References}

Allen, S. E. and Durrieu de Madron, X.: A review of the role of submarine canyons in deep-ocean exchange with the shelf, Ocean Sci., 5, 607-620, doi:10.5194/os-5-607-2009, 2009.

Armstrong, R. A., Lee, C., Hedges, J. I., Honjo, S., and Wakeham, S. G.: A new, mechanistic model for organic carbon fluxes in the ocean based on the quantitative association of POC with ballast minerals, Deep-Sea Res. Pt. II, 49, 219-236, 2002.

Bensch, A., Gianni, M., Greboval, D., Sanders, J., and Hjort, A.: Worldwide review of bottom fisheries in the high seas, FAO Fisheries and Aquaculture Technical Paper Rome, 145 pp., 2009.

Bianchi, T. S., Johansson, B., and Elmgren, R.: Breakdown of phytoplankton pigments in Baltic sediments: effects of anoxia and loss of deposit-feeding macrofauna, J. Exp. Mar. Biol. Ecol., 251, 161-183, 2000.

Bourgeois, S., Pruski, A. M., Sun, M.-Y., Buscail, R., Lantoine, F., Kerhervé, P., Vétion, G., Rivière, B., and Charles, F.: Distribution and lability of land-derived organic matter in the surface sediments of the Rhône prodelta and the adjacent shelf (Mediterranean Sea, France): a multi proxy study, Biogeosciences, 8, 3107-3125, doi:10.5194/bg-8-3107-2011, 2011.

Christie, W. W.: Lipid Analysis: Isolation, Separation, Identification and Structural Analysis of Lipids, edited by: Oily Press, 3rd Edition, 207 pp., 2003.

Clarke, K. R.: Non-parametric multivariate analyses of changes in community structure, Aust. J. Ecol., 18, 117-143, 1993.

Clarke, K. R. and Gorley, R. N.: PRIMER v5: User Manual/Tutorial, 2001.

Clarke, K. R. and Gorley, R. N.: PRIMER v6: User Manual/Tutorial, 2006.

Company, J.B., Ramirez-Llodra, E., Sardà, F., Aguzzi, J., Puig, P., Canals, M., Calafat, A., Palanques, A., Solé, M., Sanchez-Vidal, A., Martín, J., Lastras, G., Tecchio, S., Koenig, S., FernandezArcaya, U., Mechó, A., and Fernández, P.: Submarine canyons in the Catalan Sea (NW Mediterranean): megafaunal biodiversity patterns and anthropogenic threats, in: Mediterranean Submarine Canyons: Ecology and Governance, edited by: Würtz, M., IUCN, Gland, Switzerland and Málaga, Spain, 133-144 pp., 2012.

De Leo, F. C., Smith, C. R., Rowden, A. A., Bowden, D. A., and Clark, M. R.: Submarine canyons: hotspots of benthic biomass and productivity in the deep sea, P. R. Soc. Lond. B, 277, 27832792, 2010.

Duplisea, D. E., Jennings, S., Malcolm, S. J., Parker, R., and Sivyer, D. B.: Modelling potential impacts of bottom trawl fisheries on soft sediment biogeochemistry in the North Sea, Geochem. Trans., 2, 112-117, 2001.

Fabres, J., Tesi, T., Velez, J., Batista, F., Lee, C., Calafat, A., Heussner, S., Palanques, A., and Miserocchi, S.: Seasonal and eventcontrolled export of organic matter from the shelf towards the Gulf of Lions continental slope, Cont. Shelf Res., 28, 19711983, 2008.

García, R. and Thomsen, L.: Bioavailable organic matter in surface sediments of the Nazaré canyon and adjacent slope (Western Iberian Margin), J. Mar. Syst., 74, 44-59, 2008.

Graf, G.: Benthic-pelagic coupling in a deep-sea benthic community, Nature, 341, 437-439, 1989.

Granata, T. C., Vidondo, B., Duarte, C. M., Satta, M. P., and Garcia, M.: Hydrodynamics and particle transport associated with a submarine canyon off Blanes (Spain), NW Mediterranean Sea, Cont. Shelf Res., 19, 1249-1263, 1999.

Grassle, J. F. and Morse-Porteous, L. S.: Macrofaunal colonisation of disturbed deep-sea environments and the structure of deep-sea benthic communities, Deep-Sea Res., 34, 1911-1950, 1987.

Grebmeier, J. M., McRoy, C. P., and Fever, H. M.: Pelagic-benthic coupling on the shelf of the northern Bering and Chukchi Seas. I. Food supply source and benthic biomass, Mar. Ecol.-Prog. Ser., 48, 57-67, 1988.

Grémare, A., Medernach, L., deBovée, F., Amouroux, J. M., Vétion, G., and Albert, P.: Relationships between sedimentary organics and benthic meiofauna on the continental shelf and the upper slope of the Gulf of Lions (NW Mediterranean), Mar. Ecol.-Prog. Ser., 234, 85-94, 2002.

Grémare, A., Gutiérrez, D., Anschutz, P., Amouroux, J.M., DeXandre, B., and Vétion, G.: Spatio-temporal changes in totally and enzymatically hydrolyzable amino acids of superficial sediments from three contrasted areas, Prog. Oceanogr., 65, 89-111, 2005.

Haddad, R. I., Martens, C. S., and Farrington, J. W.: Quantifying early diagenesis of fatty acids in a rapidly accumulating coastal marine sediment, Org. Geochem., 19, 205-216, 1992.

Handa, N. and Tominaga, H.: A detailed analysis of carbohydrates in marine particulate matter, Mar. Biol., 2, 228-235, 1969.

Hartley, H. O.: The Use of Range in Analysis of Variance, Biometrika, 37, 271-280, 1950.

Hedges, J. I., Clark, W. A., and Cowie, G. L.: Organic matter sources to the water column and surficial sediments of a marine bay, Limnol. Oceanogr., 33, 1116-1136, 1988.

Henrichs, S. M. and Doyle, A. P.: Decomposition of ${ }^{14} \mathrm{C}$-labeled organic substances in marine sediments, Limnol. Oceanogr., 31, 765-778, 1986.

Hofmann, T., Hanlon, A. R. M., Taylor, J. D., Ball, A. S., Osborn, A. M., and Underwood, G. J. C.: Dynamics and compositional changes in extracellular carbohydrates in estuarine sediments during degradation, Mar. Ecol.-Prog. Ser., 379, 45-58, 2009.

Indarti, E., Abdul Majid, M. I., Hashim, R., and Chong, A.: Direct FAME synthesis for rapid total lipid analysis from fish oil and cod liver oil, J. Food. Compos. Anal., 18, 161-170, 2005.

Ingalls, A. E., Lee, C., Wakeham, S. G., and Hedges J. I.: The role of biominerals in the sinking flux and preservation of amino acids in the Southern Ocean along 170 degrees W, Deep-Sea Res. Pt. II, 50, 713-738, 2003.

Jones, J. B.: Environmental impact of trawling on the seabed: a review, New Zeal. J. Mar. Fresh., 26, 59-67, 1992.

Kaiser, K. and Benner, R.: Organic matter transformations in the upper mesopelagic zone of the North Pacific: Chemical composition and linkages to microbial community structure, J. Geophys. Res., 117, C01023, doi:10.1029/2011JC007141, 2012.

Kerhervé, P., Buscail, R., Gadel, F., and Seve, L.: Neutral monosaccharides in surface sediments of the northwestern Mediterranean Sea, Org. Geochem., 33, 421-435, 2002.

Laureillard, J., Pinturier, L., Fillaux, J., and Saliot, A.: Organic geochemistry of marine sediments of the Subantarctic Indian Ocean sector: Lipid classes-sources and fate, Deep-Sea Res. Pt. II, 44, 1085-1108, 1997.

Lee, C., Wakeham, S. G., and Hedges, J. I.: Composition and flux of particulate amino acids and chloropigments in equatorial Pacific seawater and sediments, Deep-Sea Res. Pt. I, 47, 1535-1568, 2000. 
Lee, C., Wakeham, S. G., and Arnosti, C.: Particulate organic matter in the sea: the composition conundrum, Ambio, 33, 565-575, 2004.

Lewis, T., Nichols, P. D., and McMeekin, T. A.: Evaluation of extraction method for recovery of fatty acids from lipid-producing microheterotrops, J. Microbiol. Meth., 43, 107-116, 2000.

Louda, J. W., Neto, R. R., Magalhaes, A. R. M., and Schneider, V. F.: Pigment alterations in the brown mussel Perna perna, Comp. Biochem. Phys. B, 150, 385-394, 2008.

Martín, J., Palanques, A., and Puig, P.: Composition and variability of downward particulate matter fluxes in the Palamós submarine canyon (NW Mediterranean), J. Mar. Syst., 60, 75-97, 2006.

Martín, J., Palanques, A., and Puig, P.: Near-bottom horizontal transfer of particulate matter in the Palamós Submarine Canyon (NW Mediterranean), J. Mar. Res., 65, 193-218, 2007.

Martín, J., Puig, P. Palanques, A., Masqué, P., and García-Orellana, J.: Effect of commercial trawling on the deep sedimentation in a Mediterranean submarine canyon, Mar. Geol., 252, 150-155, 2008.

Mayer, L. M.: Relationships between mineral surfaces and organic carbon concentrations in soils and sediments, Chem. Geol., 114, 347-363, 1994.

Mayer, L. M., Schick, L. L., Sawyer, T., Plante, C. J., Jumars, P. A., and Self, R. L.: Bioavailable amino acids in sediments: a biomimetic, kinetics-based approach, Limnol. Oceanogr., 40, 511-520, 1995.

McConnaughey, R. A., Mier, K. L., and Dew, C. B.: An examination of chronic trawling effects on soft-bottom benthos of the eastern Bering Sea, ICES J. Mar. Sci., 57, 1377-1388, 2000.

Moore, E. K., Nunn, B. L., Goodlett, D. R., and Harvey, H. R.: Identifying and tracking proteins through the marine water column: Insights into the inputs and preservation mechanisms of protein in sediments, Geochim. Cosmochim. Ac., 83, 324-359, 2012.

Morato, T., Watson, R., Pitcher, T. J., and Pauly, D.: Fishing down the deep, Fish. Fish., 7, 24-34, 2006.

Nahon, S., Charles, F., Lantoine, F., Vétion, G., Escoubeyrou, K., Desmalades, M., and Pruski, A. M.: Ultraviolet radiation negatively affects growth and food quality of the pelagic diatom Skeletonema costatum, J. Mar. Biol. Ecol., 383, 164-170, 2006.

Oakes, J. M., Eyre, B. D., Middelburg, J. J., and Boschker, H. T. S.: Composition, production, and loss of carbohydrates in subtropical shallow subtidal sandy sediments: Rapid processing and long-term retention revealed by ${ }^{13} \mathrm{C}$-labeling, Limnol. Oceanogr., 55, 2126-2138, 2010.

Opsahl, S. and Benner, R.: Characterization of carbohydrates during early diagenesis of five vascular plant tissues, Org. Geochem., 30, 83-94, 1999.

Palanques, A., Guillén, J., and Puig, P.: Impact of bottom trawling on water turbidity and muddy sediment of an unfished continental shelf, Limnol. Oceanogr., 46, 1100-1110, 2001.

Palanques, A., García-Ladona, E., Gomis, D., Martín, J., Marcos, M., Pascual, A., Puig, P., Gili, J.-M., Emelianov, M., Monserrat, S., Guillén, J., Tintoré, J., Segura, M., Jordi, A., Ruiz, S., Basterretxea, G., Font, J., Blasco, D., and Pagès, F.: General patterns of circulation, sediment fluxes and ecology of the Palamós (La Fonera) submarine canyon, northwestern Mediterranean, Prog. Oceanogr., 66, 89-119, 2005.

Palanques, A., Martín, J., Puig, P., Guillén, J., Company, J. B., and Sardà, F.: Evidence of sediment gravity flows induced by trawl- ing in the Palamós (Fonera) submarine canyon (northwestern Mediterranean), Deep-Sea Res. Pt. I, 53, 201-214, 2006.

Palanques, A., Puig, P., Guillén, J., Durrieu de Madron, X., Latasa, M., Scharek, R., and Martin, J.: Effects of storm events on the shelf-to-basin sediment transport in the southwestern end of the Gulf of Lions (Northwestern Mediterranean), Nat. Hazards Earth Syst. Sci., 11, 843-850, doi:10.5194/nhess-11-843-2011, 2011.

Pasqual, C., Lee, C., Goñi, M., Tesi, T., Sanchez-Vidal, A., Calafat, A., Canals, M., and Heussner, S.: Use of organic biomarkers to trace the transport of marine and terrigenous organic matter through the southwestern canyons of the Gulf of Lion, Mar. Chem., 126, 1-12, 2011.

Ploug, H., Iversen, M. H., and Fischer, G.: Ballast, sinking velocity, and apparent diffusivity within marine snow and zooplankton fecal pellets: Implications for substrate turnover by attached bacteria, Limnol. Oceanogr., 53, 1878-1886, 2008.

Puig, P., Canals, M., Company, J. B., Martín, J., Amblas, D., Lastras, G., Palanques, A., and Calafat, A. M.: Ploughing the deep seafloor, Nature, 489, 286-289, 2012.

Pusceddu, A., Bianchelli, S., Canals, M., Sanchez-Vidal, A., Durrieu de Madron, X., Heussner, S., Lykousis, V., de Stigter, H. C., Trincardi, F., and Danovaro, R.: Organic matter in sediments of canyons and open slopes of the Portuguese, Catalan, Southern Adriatic and Cretan Sea margins, Deep-Sea Res. Pt. I, 57, 441457, 2010.

Repeta, D. J. and Gagosian, R. B.: Carotenoid diagenesis in recent marine sediments. The Peru continental shelf $\left(15^{\circ} \mathrm{S}, 75^{\circ} \mathrm{W}\right)$, Geochim. Cosmochim. Ac., 51, 1001-1009, 1987.

Reuss, N.: Sediment pigments as biomarkers of environmental change, Ph.D. Thesis, University of Copenhagen, 33 pp., 2005.

Rodil, I. F., Lastra, M., and López, J.: Macroinfauna community structure and biochemical composition of sedimentary organic matter along a gradient of wave exposure in sandy beaches (NW Spain), Hydrobiologia, 579, 301-316, 2007.

Sun, M.-Y. and Wakeham, S. G.: Molecular evidence for degradation and preservation of organic matter in the anoxic Black Sea Basin, Geochim. Cosmochim. Ac., 58, 3395-3406, 1994.

Sun, M.-Y., Aller, R. C., and Lee, C.: Early diagenesis of chlorophyll-a in Long Island Sound sediments: A measure of carbon flux and particle reworking, J. Mar. Res., 49, 379-401, 1991.

Sun, M.-Y., Lee, C., and Aller, R. C.: Laboratory studies of oxic and anoxic degradation of chlorophyll- $a$ in Long Island Sound sediments, Geochim. Cosmochim. Ac., 57, 147-157, 1993.

Sun, M.-Y., Wakeham, S. G., and Lee, C.: Rates and mechanisms of fatty acid degradation in oxic and anoxic coastal marine sediments of Long Island Sound, New York, USA, Geochim. Cosmochim. Ac., 61, 341-355, 1997.

Tobar, R. and Sardà, F.: Análisis de la evolución de las capturas de gamba rosada, Aristeus antennatus (Risso, 1816), en los últimos decenios en Cataluña, Inf. Técn. Inv. Pesq., 142, 3-20, 1987.

Thompson, J. K. and Nichols, F. H.: Food availability controls seasonal cycle of growth in Macoma balthica (L.) in San Francisco Bay, California, J. Exp. Mar. Biol. Ecol., 116, 43-61, 1988.

Thrush, S. F. and Dayton, P. K.: Disturbance to marine benthic habitats by trawling and dredging - Implications for marine biodiversity, Annu. Rev. Ecol. Syst., 33, 449-473, 2002. 
Thrush, S. F. and Dayton, P. K.: What can ecology contribute to ecosystem-based management?, Annu. Rev. Mar. Sci., 2, 419$441,2010$.

Vetter, E. W. and Dayton, P. K.: Organic enrichment by macrophyte detritus, and abundance patterns of megafaunal populations in submarine canyons, Mar. Ecol.-Prog. Ser., 186, 137-148, 1999.

Vetter, E. W., Smith, C. R., and De Leo F. C.: Hawaiian hotspots: enhanced megafaunal abundance and diversity in submarine canyons on the oceanic islands of Hawaii, Mar. Ecol., 31, 183199, 2010.

Wakeham, S. G., Lee, C., Hedges, J. I., Hernes, P. J., and Peterson, M. L.: Molecular indicators of diagenetic status in marine organic matter, Geochim. Cosmochim. Ac., 61, 5363-5369, 1997.
Weaver, P. E., Billett, D. M., Boetius, A., Danovaro, R., Freiwald, A., and Sibuet, M.: Hotspot ecosystem research on Europe's deep-ocean margins, Oceanography, 17, 132-143, 2004.

Williams, P. J. Le B.: Incorporation of microheterotrophic processes into the classical paradigm of the planktonic food web, Kieler Meeresforsch., 5, 1-28, 1981.

World Resources Institute: A guide to world resources 2000-2001: People and Ecosystems: the Fraying web of life, 388 pp., 2000.

Wright, S. W., Jeffrey, S. W., Mantoura, R. F. C., Llewellyn, C. A., Bjørnland, T., Repeta, D., and Welschmeyer, N.: Improved HPLC method for the analysis of chlorophylls and carotenoids from marine phytoplankton, Mar. Ecol.-Prog. Ser., 77, 183-196, 1991. 